\title{
Low back pain and methods of coping with low back pain in
}

\section{nurses}

\author{
Hemşirelerde bel ağrısı ve bel ağrısıyla baş etme yöntemleri
}

(1) Cüneyt GÜNDÜZ,' @ Aylin AYDIN SAYILAN²

\begin{abstract}
Summary
Objectives: This research was conducted to determine low back pain in nurses and their methods of coping with low back pain. Methods: This descriptive, cross-sectional study was performed with 356 nurses in three university hospitals in the province of Istanbul in April-August 2016. Percentage calculations and Chi-square tests were used in statistical analyses.

Results: The mean age of the nurses in the study was $28.70 \pm 5.92,25.3 \%$ were working in intensive care, $46.6 \%$ worked $41-48$ $\mathrm{h}$ a week, and $55.6 \%$ stood for $5-8 \mathrm{~h}$ within a $24 \mathrm{~h}$ period. Low back pain was moderate in $75.8 \%$ of participants, and low back pains sometimes affected work efficiency in $43.3 \%(n=154)$. In terms of coping, the great majority of participants did not visit a physician, but used analgesics, avoided wearing high-heeled shoes, and slept in hard beds. Statistical significance $(p<0.05)$ was observed between participants' age groups, the unit where they worked, type of duty, the amount of time spent standing, and the amount of time standing in the same position and low back pain.
\end{abstract}

Conclusion: Based on the results obtained, nurses experienced a moderate level of low back pain, and we think that experiencing low back pain is a continuous risk for nurses because of their lengthy hours of work and time spent standing, and that their working hours should, therefore, be adjusted and that correct body mechanics should be included during in-service training.

Keywords: Back pain; coping; nurse.

\section{Özet}

Amaç: Bu araştırma, hemşirelerde bel ağrısı ve bel ağrısıyla baş etme yöntemlerinin belirlenmesi amacıyla yapıldı.

Gereç ve Yöntem: Tanımlayıcı, kesitsel tipte olan çalışma, Nisan-Ağustos 2016 tarihlerinde İstanbul Ili'nde yer alan 3 üniversite hastanesinde, 356 hemşireyle gerçekleştirildi. İstatistiksel değerlendirmede yüzdelik hesaplama, ki-kare testleri kullanıldı.

Bulgular: Çalışmada, hemşirelerin yaş ortalaması $28.70 \pm 5.92$ olup, $\% 25,3$ 'ünün yoğun bakımda çalıştı̆ı̆, $\% 46,6$ 'sının haftada 41- 48 saat arası çalıştığı, \%55,6'sının 24 saat içerisinde 5-8 saat arası ayakta kaldığı belirlendi. Katılımcıların \%75,8'inde mevcut bel ağrısı şiddetinin orta düzeyde olduğu, \%43,3'ünde ( $n=154)$ bel ağrılarının çalışma verimini bazen etkilediği görüldü. Baş etme yöntemi olarak, büyük bir çoğunluğun hekime gitmediği, analjezik aldığı, topuklu ayakkabı giymedikleri, sert yatakta yattıkları görüldü. Katılımcıların yaş grupları, çalıştı̆̆ı birim, görev durumu, ayakta durma süresi, aynı pozisyonda durma süresi ile bel ağrısı arasında istatistiksel anlamlıık $(p<0.05)$ olduğu görüldü.

Sonuç: Çalışmadan elde edilen sonuçlar doğrultusunda; hemşirelerin orta düzeyde bel ağrısı deneyimlediği, bel ağrısı yaşamanın, uzun süreli çalışma ve ayakta kalma nedeniyle hemşireler için sürekli bir risk olduğu; bu sonuç doğrultusunda çalışma saatlerinin düzenlenmesi ve doğru vücut mekaniklerine eğitimlerde yer verilmesi gereği düşünüldü.

Anahtar sözcükler: Bel ağrısı; baş etme; hemşire.

\section{Introduction}

Pain and musculoskeletal diseases due to exposure to physical and psychosocial risks are among the most common health problems that nurses encounter in their professional lives. ${ }^{[1]}$ Studies in the literature report that the incidence of low back pain in nurses varies between $40 \%$ and $97.9 \%$, and this high rate is regarded as an occupational problem. ${ }^{[2,3]} \mathrm{A}$ recent study determined incidence of low back pain in nurses of $66.8 \%$ for 1 -year prevalence and $51.3 \%$ for point prevalence, and described this as an occupational problem. ${ }^{[4]}$

${ }^{1}$ Kırklareli University, Institute of Health Sciences, Kırklareli, Turkey

${ }^{2}$ Department Nursing, Kırklareli University Health Science Faculty, Kırklareli, Turkey

Submitted (Başvuru tarihi) 05.03.2020 Accepted after revision (Düzeltme sonrası kabul tarihi) 25.01.2021 Available online date (Online yayımlanma tarihi) 25.08.2021

Correspondence: Dr. Aylin Aydın Sayılan. Kırklareli Üniversitesi Sağlık Bilimleri Fakültesi, Hemşirelik Bölümü, Kırklareli, Turkey.

Phone: +90 - 288 - 2145547 e-mail: aylin.sayilan@klu.edu.tr

(c) 2021 Turkish Society of Algology 
Some of the main reasons for this frequent problem experienced problem in nurses are prolonged working hours and prolonged time spent sitting or standing, weight lifting, use of the body in incorrect positions, ergonomic deficiencies arising from the working environment, and workload. ${ }^{[5]}$ Besides these reasons, psychosocial factors such as work monotony, job dissatisfaction, social support, a heavy workload, intense responsibility, lack of relaxation opportunities in the work environment, working without a break, and inadequate work organization also play a role in the development of low back pain. ${ }^{[6]}$

In addition to physical and psychosocial risk factors, one previous study also identified factors such as gender, height, age, weight, body mass index (BMI), exercise, smoking, educational and marital status, working time, and working style as risk factors associated with low back pain. ${ }^{[1]}$

Low back pain is also a frequent cause of disability among nurses, ${ }^{[7]}$ and alternative methods such as avoiding high-heeled shoes, prayer, hot spring (hot water), massage, listening to music, and acupuncture are used in coping with this pain. ${ }^{[4,8]}$

Nurses are still at high risk for low back pain, ${ }^{[3,4]}$ which disrupts their activity levels, interpersonal relationships, and work performance and also causes sleep problems. Patient care and quality of life decrease as a result. ${ }^{[3,9]}$

The aim of this study was, therefore, to determine the levels of low back pain in nurses and their methods of coping with it.

\section{Material and Methods}

This descriptive, cross-sectional study aimed to determine low back pain in nurses and their methods of coping with low back pain. The study population consisted of all nurses ( $N$ : 873) working in three hospitals in the province of İstanbul, Turkey. The study sample consisted of nurses ( $n$ : 356) working in these three hospitals between April and August 2016. Participants consisted of nurses who were in the hospital during data collection and agreed to participate in the study.

The inclusion criteria for the study were age 18 years or more, have no difficulty in communication, having no low back pain before starting in the profession, working at the current clinic for at least 1 year, and willingness to participate in the study. The response rate was $40.77 \%$.

\section{Data collection form}

As a data collection tool, a personal information form prepared by the researchers based on the literature review was used. ${ }^{[1,2,4,6]}$ This included 15 questions regarding the sociodemographic characteristics of the participants (age, gender, marital, educational and smoking status, BMI, length of time worked, and the clinic at which the nurses worked) and the characteristics about their disease. It took 15-20 min to complete the form. The Cronbach alpha value of the questionnaire in this study was 0.863 .

\section{The data collection method}

Information was given with regard to the purpose and method of this study, and verbal permission was obtained from the nurses who agreed voluntarily to participate. The nurses were asked to answer these questions through face-to-face interviews, and this took approximately 15-20 min for each nurse. The data collection tools were distributed once the nurses agreeing to take part had been given the requisite information about them, and were collected after completion.

\section{Analysis of the study}

In the analysis of the data, Statistical Package for the Social Science (SPSS Ltd., Chicago, IL, USA) 20.0 software package program and SAS package program (Statistical Analysis System, Version 9, SAS Institute, Cary, NC) were used. In addition to the descriptive statistical methods (mean, standard deviation, and frequency), Mann-Whitney $\mathrm{U}$ and Kruskal-Wallis $\mathrm{H}$ tests were also used for comparisons between the two groups.

\section{The ethical dimension}

Permission for the study was received from the Istanbul Provincial Health Directorate under decision No. 07 dated October 16, 2015. Written approval was granted by the Kirklareli University Non-Interventional Clinical Research Ethical Committee, and written and verbal informed consent was given by all participants.

\section{Limitations of the study}

The limitations of the study are that many nurses were on leave and on sick leave between the study 
Table 1. Distribution of patients according to their sociodemographic and work characteristics

\begin{tabular}{|c|c|c|c|c|c|}
\hline & $\mathbf{n}$ & $\%$ & & $\mathbf{n}$ & $\%$ \\
\hline Age (year) & & & Total & 356 & 100.0 \\
\hline Mean $\pm S D^{*}=28.70 \pm 5.92 ;$ Min. - Max $=19-47$ & & & Working experience & & \\
\hline 23 years old and below & 96 & 27.0 & 1 year and below & 53 & 14.9 \\
\hline 24-28 years old & 91 & 25.6 & $2-5$ years & 124 & 34.8 \\
\hline 29-33 years old & 95 & 26.7 & $6-10$ years & 102 & 28.7 \\
\hline $34-38$ years old & 19 & 5.3 & $11-15$ years & 29 & 8.1 \\
\hline 39 years and over & 55 & 15.4 & 16 years and over & 48 & 13.5 \\
\hline Total & 356 & 100.0 & Total & 356 & 100.0 \\
\hline Gender & & & The unit where the nurses work & & \\
\hline Male & 37 & 10.4 & Internal medicine & 83 & 23.3 \\
\hline Female & 319 & 89.6 & Surgical units & 183 & 51.4 \\
\hline Total & 356 & 100.0 & Intensive care & 90 & 25.3 \\
\hline Marital status & & & Total & 356 & 100.0 \\
\hline Married & 153 & 43.0 & Weekly working hours & & \\
\hline Single & 203 & 57.0 & $40 \mathrm{~h}$ & 155 & 43.5 \\
\hline Total & 356 & 100.0 & $41-48 \mathrm{~h}$ & 166 & 46.6 \\
\hline Educational status & & & $49 \mathrm{~h}$ and more & 35 & 9.8 \\
\hline Medical vocational high school & 46 & 12.9 & Total & 356 & 100.0 \\
\hline Associate degree & 70 & 19.7 & The amount of time spent standing & & \\
\hline Undergraduate & 216 & 60.7 & $4 \mathrm{~h}$ and below & 33 & 9.3 \\
\hline Postgraduate & 24 & 6.7 & $5-8 h$ & 198 & 55.6 \\
\hline Total & 356 & 100.0 & $9 \mathrm{~h}$ and over & 125 & 35.1 \\
\hline Smoking & & & Total & 356 & 100.0 \\
\hline Yes & 125 & 35.1 & The amount of time spent staying & & \\
\hline No & 231 & 64.9 & in the same position & & \\
\hline Total & 356 & 100.0 & $1 \mathrm{~h}$ and below & 293 & 82.3 \\
\hline Body mass index & & & $1-2 \mathrm{~h}$ & 29 & 8.1 \\
\hline Underweight $(<18.4)$ & 104 & 29.2 & $2-3 \mathrm{~h}$ & 14 & 3.9 \\
\hline Normal weight (18.5-24.9) & 175 & 49.2 & $4 \mathrm{~h}$ and over & 20 & 5.7 \\
\hline Overweight (25-29.9) & 77 & 21.6 & Total & 356 & 100.0 \\
\hline
\end{tabular}

*: The difference in numbers is due to male gender; SD: Standard deviation.

dates, or could not spare enough time to complete the forms due to their busy schedule, and that generalization was not possible since the study was conducted in three hospitals.

\section{Results}

The mean age of the nurses was $28.70 \pm 5.92$ years, $89.6 \%(n=319)$ were women, $60.7 \%(n=216)$ were graduates, $64.9 \%$ were non-smokers, and $49.2 \%(n=175)$ had normal BMI values. In addition, 34.8\% $(n=124)$ had 2-5 years' professional experience and $28.7 \%(n=102)$ 6-10 years' experience.
Analysis showed that $25.3 \%(n=90), 23.3 \%(n=83)$, and $51.4 \%(n=183)$ of the nurses were employed in the intensive care, internal medicine, and surgical units, respectively, and $82.8 \%(n=295)$ were working as inpatient service nurses.

In terms of working hours, $46.6 \%(n=166)$ of the participants worked $41-48 \mathrm{~h}$ a week, while $43.5 \%$ worked $40 \mathrm{~h}$ or less. In addition, $55.6 \%$ $(\mathrm{n}=198)$ stood for $5-8 \mathrm{~h}$ within a $24 \mathrm{~h}$ period, and $82.3 \%(n=293)$ remained in the same position for $1 \mathrm{~h}$ (Table 1 ). 
Table 2. Nurses' opinions on back pain

\begin{tabular}{|c|c|c|c|c|c|}
\hline Descriptive characteristics & $\mathbf{n}$ & $\%$ & Descriptive characteristics & $\mathbf{n}$ & $\%$ \\
\hline \multirow{2}{*}{$\begin{array}{l}\text { Consulting a physician due to low back } \\
\text { pain in the past year }\end{array}$} & & & Sometimes & 154 & 43.3 \\
\hline & & & Total & 356 & 100.0 \\
\hline Yes & 120 & 33.7 & \multirow{2}{*}{$\begin{array}{l}\text { Having been transferred to a unit with } \\
\text { a less workload due to low back pain }\end{array}$} & & \\
\hline No & 236 & 66.3 & & & \\
\hline Total & 356 & 100.0 & Yes & 86 & 24.2 \\
\hline \multirow{2}{*}{$\begin{array}{l}\text { Having a medical intervention } \\
\text { for low back pain }\end{array}$} & & & No & 270 & 75.8 \\
\hline & & & Total & 356 & 100.0 \\
\hline Yes & 123 & 34.6 & \multirow{2}{*}{$\begin{array}{l}\text { Having a low back pain affecting } \\
\text { job satisfaction }\end{array}$} & & \\
\hline No & 233 & 65.4 & & & \\
\hline Total & 356 & 100.0 & Yes & 201 & 56.5 \\
\hline \multirow{2}{*}{\multicolumn{3}{|c|}{$\begin{array}{l}\text { Type of medical intervention for } \\
\text { low back pain }\end{array}$}} & No & 155 & 43.5 \\
\hline & & & Total & 356 & 100.0 \\
\hline Physiotherapy & 78 & 63.4 & \multicolumn{3}{|l|}{ Activities affected by low back pain } \\
\hline Medication & 45 & 36.6 & \multirow{2}{*}{$\begin{array}{l}\text { Weight lifting (1) - Walking (2) - Sitting (3) } \\
(1) \text { - Standing (4) - Sleeping (5) }\end{array}$} & 10 & 2.8 \\
\hline & 123 & 100.0 & & 8 & 2.2 \\
\hline \multicolumn{3}{|l|}{ Using medication for low back pain } & (1) - (4) - House work (6) & 4 & 1.1 \\
\hline Yes & 234 & 65.7 & $(1)-(5)-(6)$ & 6 & 1.7 \\
\hline No & $\begin{array}{l}122 \\
356\end{array}$ & 34.3 & (1) - Social activities (7) - Sex life (8) & 4 & 1.1 \\
\hline \multicolumn{3}{|l|}{ Medications used for low back pain } & $(1)-(2)-(3)-(4)$ & 42 & 11.8 \\
\hline NSAll & 35 & 15.0 & $(1)-(2)-(3)-(5)$ & 10 & 2.8 \\
\hline Paracetamol & 42 & 18.0 & $(1)-(2)-(5)-(8)$ & 8 & 2.2 \\
\hline Muscle relaxant & 126 & 53.8 & $(1)-(3)-(5)-(6)$ & 2 & 0.6 \\
\hline Paracetamol and muscle relaxant & 31 & 13.2 & $(1)-(4)-(5)-(6)$ & 14 & 3.9 \\
\hline Total & 234 & 100.0 & $(1)-(4)-(6)-(7)$ & 49 & 13.8 \\
\hline \multicolumn{3}{|l|}{ Severity of low back pain } & $(1)-(5)-(6)-(8)$ & 2 & 0.6 \\
\hline Moderately severe & 270 & 75.8 & $(1)-(3)-(4)-(5)-(6)$ & 36 & 10.1 \\
\hline Very severe & 86 & 24.2 & $(1)-(3)-(4)-(6)-(7)$ & 35 & 9.8 \\
\hline Total & 356 & 100.0 & $(1)-(4)-(5)-(6)-(8)$ & 2 & 0.6 \\
\hline \multirow{2}{*}{\multicolumn{3}{|c|}{$\begin{array}{l}\text { Having a low back pain affecting work } \\
\text { efficiency and performance }\end{array}$}} & $(2)-(3)-(4)-(5)-(6)$ & 45 & 12.6 \\
\hline & & & $(1)-(2)-(3)-(4)-(5)-(6)-(8)$ & 2 & 0.6 \\
\hline Yes & 78 & 21.9 & $(1)-(2)-(3)-(4)-(5)-(6)-(7)-(8)$ & 77 & 21.6 \\
\hline No & 124 & 34.8 & Total & 356 & 100.0 \\
\hline
\end{tabular}

Table 2 includes the participants' opinions regarding low back pain and shows that $66.3 \%(n=236)$ had not consulted a physician due to low back pain in the previous year, and that $65.4 \%(n=233)$ received no intervention for it.

In addition, 53.8\% $(n=126)$ of the 234 nurses who used medication for their low back pain used muscle relaxants.

About $8 \%$ of the participants, the severity of low back pain was moderate, $43.3 \%(n=154)$ had a low back pain that sometimes affected their work efficiency and $75.8 \%(n=270)$ had not ask for being transferred to a unit with a less workload due to their low back pain.

It was determined that in $56.5 \%(n=201)$ of the participants, low back pain affected job satisfaction, and most affected activities due to low back pain were weight lifting, walking, sitting, standing, sleeping, housework, social activities, and sex life for $21.6 \%$ $(n=77)$ of the participants and weight lifting, standing, housework, and social activities for $13.8 \%(n=49)$. 
Table 3. Nurses' coping methods to reduce their low back pain

\begin{tabular}{|c|c|c|c|c|c|c|}
\hline \multirow[t]{2}{*}{ Methods } & \multicolumn{2}{|c|}{ Yes } & \multicolumn{2}{|c|}{ Sometimes } & \multicolumn{2}{|c|}{ No } \\
\hline & $\mathbf{n}$ & $\%$ & $\mathbf{n}$ & $\%$ & $\mathbf{n}$ & $\%$ \\
\hline Moving arms, shoulders, and hips in alignment & 134 & 37.6 & 42 & 11.8 & 180 & 50.6 \\
\hline Keeping head in front and abdomen in & 134 & 37.6 & 42 & 11.8 & 180 & 50.6 \\
\hline Not standing for long & 125 & 35.1 & 84 & 23.6 & 147 & 41.3 \\
\hline Avoiding wearing high-heeled shoes when you have to stand for a long time & 169 & 47.5 & 42 & 11.8 & 145 & 40.7 \\
\hline Not sitting in the same position for a long time & 126 & 35.4 & 84 & 23.6 & 146 & 41.0 \\
\hline $\begin{array}{l}\text { Putting one foot on the step - high support and changing it every } \\
5-15 \text { min when you have to stand for a long time }\end{array}$ & 45 & 12.6 & 87 & 24.4 & 224 & 62.9 \\
\hline Putting the pillow under your knees and waist cavity while lying on your back & 45 & 12.6 & 86 & 24.2 & 225 & 63.2 \\
\hline Lying on side with knees bent & 42 & 11.8 & 86 & 24.2 & 228 & 64.2 \\
\hline Putting pillow between legs while lying on side & 87 & 24.4 & 44 & 12.4 & 225 & 63.2 \\
\hline Supporting the back and waist cavity while sitting & 80 & 22.5 & 209 & 58.7 & 67 & 18.8 \\
\hline Sleeping in hard bed & 89 & 25.0 & 42 & 11.8 & 225 & 63.2 \\
\hline Not carrying heavy objects & 193 & 54.2 & 84 & 23.6 & 35 & 9.8 \\
\hline Pushing heavy objects instead of pulling them & 190 & 53.4 & 131 & 36.8 & 35 & 9.8 \\
\hline $\begin{array}{l}\text { Bending down with your back upright instead of bending from your } \\
\text { waist when carrying things }\end{array}$ & 87 & 24.4 & 131 & 36.8 & 103 & 28.9 \\
\hline Exercising to strengthen waist muscles & 80 & 22.5 & 167 & 46.9 & 109 & 30.6 \\
\hline Doing simple exercises such as walking in a way that does not tire you & 116 & 32.6 & 131 & 36.8 & 109 & 30.6 \\
\hline Trying to lose weight & 89 & 25.0 & 129 & 36.2 & 138 & 38.8 \\
\hline Having bed rest during painful period & 166 & 46.6 & 123 & 34.6 & 67 & 18.8 \\
\hline Applying ice to the painful area & 36 & 10.1 & 44 & 12.4 & 276 & 77.5 \\
\hline Applying hot to the painful area & 112 & 31.5 & 42 & 11.8 & 202 & 56.7 \\
\hline Massaging or having someone massage on painful area & 236 & 66.3 & 42 & 11.8 & 78 & 21.9 \\
\hline Massaging the painful area using a massager & 112 & 31.5 & 42 & 11.8 & 202 & 56.7 \\
\hline Using pain killers & 116 & 32.6 & 84 & 23.6 & 156 & 43.8 \\
\hline Using muscle relaxants & 125 & 35.1 & 84 & 23.6 & 147 & 41.3 \\
\hline Using antidepressants & 0 & 0.00 & 0 & 0.0 & 356 & 100.0 \\
\hline Wearing low back corset & 36 & 10.1 & 0 & 0.0 & 320 & 89.9 \\
\hline Having Hijama therapy & 0 & 0.0 & 0 & 0.0 & 356 & 100.0 \\
\hline Having cupping (dry) therapy & 0 & 0.00 & 0 & 0.0 & 356 & 100.0 \\
\hline Having leech therapy & 0 & 0.00 & 0 & 0.0 & 356 & 100.0 \\
\hline Using cataplasm & 0 & 0.00 & 0 & 0.0 & 356 & 100.0 \\
\hline
\end{tabular}

It was found that more than $50 \%$ of the participants answered "no" to the following questions; Moving arms, shoulders and hips in alignment, keeping head in front and abdomen in, putting one foot on the step-high support and changing it every 5-15 min when you have to stand for a long time, putting the pillow under your knees and waist cavity while lying on your back, lying on side with knees bent, sleeping in hard bed, applying ice to the painful area, applying hot to the painful area, mas- saging the painful area using a massager and wearing a low back corset.

All the participants stated that they did not "use antidepressant drugs, have Cupping (Hijama in Arabic), leech therapy or use cataplasm."

The majority of the participants replied "yes" to the following questions; "avoiding wearing high-heeled shoes when you have to stand for a long time, not 
carrying heavy objects, pushing heavy objects instead of pulling them, having bed rest during painful period and massaging or having someone massage on painful area.

Nearly half or more of the participants answered the following questions as "sometimes;" supporting the back and waist cavity while sitting, bending down with your back upright instead of bending from your waist when carrying things, exercising to strengthen waist muscles, doing simple exercises such as walking in a way that does not tire you (Table 3)."

The Cronbach' alpha level of the responses to these items was found 0.85 .

A significant relationship was found between the age groups of the participants and low back pain $(p=0.004)$, and between low back pain and task type $(p=0.003)$, time spent standing $(p=0.007)$, and remaining in the same position $(p=0.000)$.

There was not any significant correlation between the nurses' hospitals, gender, marital status, smoking status, BMI, having birth, and the number of births, the units they work in, weekly working hours, and low back pain $(p>0.05)$ (Table 4).

\section{Discussion}

Low back pain is regarded as a disability and one of the most important health problems today. It is also common problem affecting health professionals, especially nurses.

Various studies of health workers have shown a positive relationship between low back pain and high BMI, smoking, age, gender, number of shifts worked, and inappropriate posture at work, but have reported that exercise prevents low back pain. ${ }^{[10,11]}$ In the present study, $66.9 \%$ of participants did not take regular exercise, $78.1 \%$ had moderate activity levels during leisure activities, $87.4 \%$ did not wear shoes with heels higher than $3.5 \mathrm{~cm}, 55.3 \%$ frequently complained of headache, $54.5 \%$ were sometimes satisfied with the work they did, $37.1 \%$ sometimes felt safe in their workplace, $56.7 \%$ thought that they sometimes had control over their work, $65.7 \%$ never thought that their work was monotonous and boring, $75.6 \%$ stated that there was no opportunity/ activity for relaxation in their working environment, $65.7 \%$ reported no support and encouragement in the working environment, $75.6 \%$ thought that their work was always physically strenuous, $88.2 \%$ thought that the working environment was stressful, and $53.4 \%$ encountered no physical stress factor. Davis and Kotowski (2015) found that 57 (26.2\%), 120 (55\%), and 41 (18.8\%) nurses experienced mild, moderate, and severe low back pain, respectively, and that 49 had consulted a physician. ${ }^{[1]}$ Physical therapy, neurosurgery, orthopedics, and algology were the most frequently consulted departments for low back pain. In this study, it was seen that nurses' opinions about low back pain were similar to the literature. About $66.3 \%$ did not see a physician because of their low back pain in the past year, $65.4 \%$ did not have any intervention for it, $35.4 \%$ used muscle relaxants, $75.8 \%$ had moderately severe back pain, $43.3 \%$ had a low back pain which sometimes affected their work efficiency, $75.8 \%$ did not ask for being transferred to a unit with a less workload, and $6.5 \%$ had a low back pain that affected their job satisfaction. In addition, mostly affected activities were listed as weight lifting, walking, sitting, standing, sleeping, housework, social activities, and sex life by $21.6 \%$ of the participants and weight lifting, standing, housework, and social activities by $13.8 \%$. Since all of the participants had low back pain, they did not receive any training regarding the reasons and prevention of occupational back pain, they did not have any musculoskeletal system diseases before starting the profession, their low back pain began after starting the nursing profession and they did not get sick leave due to back pain, they were not included in the table. It is thought that the probability of low back pain increases in health care workers due to severe working conditions.

In a study by Sanjoy et al., ${ }^{[12]} 61.92 \%$ of 365 participants stated that physical activity had an effect on low back pain, and the most common physical activities were leaning forward, lifting things, standing, and sitting, respectively. Similar to the literature, more than $50,0 \%$ of the participants in this study expressed that assisting the patients while walking them or taking them to the bathroom/toilet would not lead to low back pain, while $77.5 \%$ thought that other applications such as carrying heavy medical equipment, heavy objects/materials pushing, pull- 
Table 4. The relationship between the participants' sociodemographic characteristics and their low back pain

\section{Sociodemographic characteristics}

The severity of low back pain

\begin{tabular}{|c|c|c|c|c|}
\hline \multicolumn{2}{|c|}{ Moderately severe } & \multicolumn{2}{|c|}{ Very severe } & \multirow[t]{2}{*}{ Mean \pm SD } \\
\hline $\mathbf{n}$ & $\%$ & $\mathbf{n}$ & $\%$ & \\
\hline
\end{tabular}

\section{Age (years)}

23 years and below $(n=96)$

73

24-28 years old $(n=91)$

$29-33$ years old $(n=95)$

$34-38$ years old $(n=55)$

39 years old and over $(n=19)$

Test value

Significance

Gender

Male $(n=37)$

Female $(n=319)$

Test value

Significance

Marital status

Married $(n=153)$

Single $(n=203)$

Test value

Significance

Educational status

Medical vocational high school $(n=46)$

35

Associate degree $(n=70)$

Undergraduate $(n=216)$

Postgraduate $(n=24)$

Test value

Significance

Smoking

$$
\text { Yes }(n=125)
$$$$
\text { No }(n=231)
$$

Test value

Significance

Body mass index

Underweight $(n=104)$

Normal weight $(n=175)$

Overweight $(n=77)$

Test value

Significance

Having birth

$$
\begin{aligned}
& \text { Yes }(n=107) \\
& \text { No }(n=249)^{*}
\end{aligned}
$$

Test value

Significance

The number of births

$$
0(n=246)^{*}
$$

19

25

245

111

159

176

22

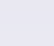

$$
\text { (1) }
$$

79

131

60

81

189

186
27.0

23.4

24.5

18.1

7.0

23

26.7

32.6

33.7

7.0

0.0

34.8

65.2

41.1

58.9

42

44

48.8

51.2

14.0

86.0

12

74

13.0

20.0

58.9

8.1

29.3

48.5

22.2

31

55

11

16

57

2

12.8

18.6

66.3

2.3

36.0

64.0

25

44

29.1

51.2

19.7

17

19.7

30.0
70.0

26

60

30.2

69.8

$2.24 \pm 0.43$

$2.24 \pm 0.42$

$M W=13294.5$

$\mathrm{p}=0.967$

68.9

60

69.8

$2.24 \pm 0.43$ 
Table 4 (cont.). The relationship between the participants' sociodemographic characteristics and their low back pain

\begin{tabular}{|c|c|c|c|c|c|}
\hline \multirow[t]{3}{*}{ Sociodemographic characteristics } & \multicolumn{5}{|c|}{ The severity of low back pain } \\
\hline & \multicolumn{2}{|c|}{ Moderately severe } & \multicolumn{2}{|c|}{ Very severe } & \multirow[t]{2}{*}{ Mean \pm SD } \\
\hline & $\mathbf{n}$ & $\%$ & $\mathbf{n}$ & $\%$ & \\
\hline $1(n=58)$ & 47 & 17.4 & 11 & 12.8 & $2.19 \pm 0.39$ \\
\hline $2(n=50)$ & 35 & 13.0 & 15 & 17.4 & $2.30 \pm 0.46$ \\
\hline $3(n=2)$ & 2 & 0.7 & 0 & 0.0 & $2.00 \pm 0.00$ \\
\hline Test value & & & & & $\mathrm{KW}=2.422$ \\
\hline Significance & & & & & $p=0.489$ \\
\hline \multicolumn{6}{|l|}{ Number of children } \\
\hline $0(n=238)$ & 182 & 67.4 & 56 & 65.1 & $2.24 \pm 0.43$ \\
\hline $1(n=60)$ & 47 & 17.4 & 13 & 15.1 & $2.24 \pm 0.43$ \\
\hline $2(n=58)$ & 41 & 15.2 & 17 & 19.8 & $2.24 \pm 0.43$ \\
\hline Test value & & & & & $K W=1.092$ \\
\hline Significance & & & & & $p=0.579$ \\
\hline \multicolumn{6}{|l|}{ The unit you work } \\
\hline Internal medicine $(n=83)$ & 61 & 22.6 & 22 & 25.6 & $2.27 \pm 0.44$ \\
\hline Surgical units ( $n=183$ ) & 145 & 53.7 & 38 & 44,2 & $2.21 \pm 0.40$ \\
\hline Intensive care $(\mathrm{n}=90)$ & 64 & 23.7 & 26 & 30.2 & $2.29 \pm 0.45$ \\
\hline Test value & & & & & $\mathrm{KW}=2.492$ \\
\hline Significance & & & & & $p=0.288$ \\
\hline \multicolumn{6}{|l|}{ Task type } \\
\hline Nurse in charge $(n=35)$ & 38 & 14.1 & 1 & 1.2 & $2.03 \pm 0.16$ \\
\hline Inpatient service nurse $(\mathrm{n}=229)$ & 215 & 79.6 & 80 & 93.0 & $2.27 \pm 0.44$ \\
\hline Polyclinic nurse $(n=6)$ & 17 & 6.3 & 5 & 5.8 & $2.23 \pm 0.42$ \\
\hline Test value & & & & & $K W=11.330$ \\
\hline Significance & & & & & $p=0.003^{*}$ \\
\hline \multicolumn{6}{|l|}{ Weekly working hours } \\
\hline $40 \mathrm{~h}(\mathrm{n}=155)$ & 118 & 43.7 & 37 & 43.0 & $2.24 \pm 0.42$ \\
\hline $41-48$ h ( $n=166)$ & 124 & 45.9 & 42 & 48.8 & $2.25 \pm 0.43$ \\
\hline $49 \mathrm{~h}$ and over $(\mathrm{n}=35)$ & 28 & 10.4 & 7 & 8.2 & $2.20 \pm 0.40$ \\
\hline Test value & & & & & $\mathrm{KW}=0.454$ \\
\hline Significance & & & & & $\mathrm{p}=0.797$ \\
\hline \multicolumn{6}{|l|}{ Time spent standing } \\
\hline $4 \mathrm{~h}$ and below $(n=33)$ & 18 & 6.7 & 15 & 17.4 & $2.24 \pm 0.43$ \\
\hline $5-8 h(n=198)$ & 151 & 55.9 & 47 & 54.7 & $2.24 \pm 0.43$ \\
\hline $9 \mathrm{~h}$ and over $(\mathrm{n}=125)$ & 101 & 37.4 & 24 & 27.9 & $2.24 \pm 0.43$ \\
\hline Test value & & & & & $K W=9.838$ \\
\hline Significance & & & & & $p=0.007^{*}$ \\
\hline \multicolumn{6}{|l|}{ Time spent staying in the same position } \\
\hline Up to $1 \mathrm{~h}(\mathrm{n}=293)$ & 219 & 81.1 & 74 & 86.0 & $2.45 \pm 0.50$ \\
\hline $1-2 \mathrm{~h}(\mathrm{n}=29)$ & 23 & 8.5 & 6 & 7.0 & $2.24 \pm 0.42$ \\
\hline $2-3 h(n=14)$ & 14 & 5.2 & 0 & 0.0 & $2.19 \pm 0.39$ \\
\hline $4 \mathrm{~h}$ and over $(n=20)$ & 14 & 5.2 & 6 & 7.0 & $2.24 \pm 0.42$ \\
\hline Test value & & & & & $K W=28.060$ \\
\hline Significance & & & & & $\mathrm{p}=0.000^{*}$ \\
\hline
\end{tabular}

*: The difference in numbers is due to male gender; SD: Standard deviation. 
ing heavy objects/materials, and changing the position of the patient would cause it. According to the literature, the most important factor that can cause low back pain in nurses can be said to be the removal and transport of patients.

Van Hoof et al. ${ }^{[13]}$ found that $89.8 \%$ of the nurses had some applications regarding their low back pain; $58.1 \%$ preferred to rest frequently and $28 \%$ preferred to use medication. In this study, it is seen that the applications used for low back pain are quite similar to the literature. The participants answered "yes" to the following questions such as "avoiding wearing high-heeled shoes when you have to stand for a long time, not carrying heavy goods, pushing heavy goods instead of pulling them while moving, having bed rest during the painful period, massaging/ having someone massage to the painful area." Nearly or more than half of the participants replied the following questions as "sometimes;" supporting the back and waist cavity while sitting, bending down with your back upright instead of bending from your waist when carrying things, exercising to strengthen waist muscles, and doing simple exercises such as walking in a way that does not tire you.

In a study by Şimşek et al., ${ }^{[14]}$ a significant relationship was found between gender and low back painand it was reported that women had more pain than men. This may be due to anatomical, physiological, and structural differences between men and women. As for this study, it was observed that there was a significant relationship between the age groups, the unit they worked in, the task type, the amount of time spent standing and staying in the same position and low back pain. However, no significant relationship found between nurses' hospitals/units, gender, marital and smoking status, BMI, having birth, number of births, weekly working time, and low back pain.

Matsudaira et al. ${ }^{[15]}$ reported that there was a significant difference in terms of job satisfaction between those with and without low back pain, and that those who were satisfied with their job had a lower incidence of low back pain. Barnish and Barnish ${ }^{[16]}$ revealed that unlike those who did not wear highheeled shoes $(66.2 \%)$, the ones wearing high-heeled shoes $(62.7 \%)$ had low back pain. In parallel with the literature, this study found a significant positive rela- tionship between fatigue and low back pain, between the job satisfaction and low back pain, between satisfaction with working style and low back pain, between regular exercise and low back pain, between having intervention and low back pain, and between wearing high-heeled shoes and low back pain.

Limitations of the study can be listed as follows; some of the nurses were off duty, some of them were on sick leave, some could not take time to fill out the forms due to their heavy workload at the time of the study, and a generalization cannot be made as the study was conducted only in three hospitals.

\section{Conclusion}

In light of the results in this study, it is seen that experiencing a low back pain is a risk for nurses due to prolonged working and standing hours. Therefore, it is suggested that nurses' working hours should be arranged and appropriate body mechanics should be included in their in-service trainings.

Ethical Approval: Following the determination of the research subject and the hospitals to be studied, the ethics committee permission was obtained from Kirklareli University Institute of Health Sciences (No. 07 dated October 16, 2015). Before the data collection, written permission was obtained from the managers of the institutions where the study will be conducted. The nurses included in the study were informed about the aim of the study, and their verbal and informed written permissions were taken.

Conflict-of-interest issues regarding the authorship or article: None declared.

Peer-rewiew: Externally peer-reviewed.

\section{References}

1. Davis KG, Kotowski SE. Prevalence of musculoskeletal disorders for nurses in hospitals, long-term care facilities, and home health care: a comprehensive review. Hum Factors 2015;57(5):754-92. [CrossRef]

2. Freimann T, Pääsuke $M$, Merisalu E. Work-related psychosocial factors and mental health problems associated with musculoskeletal pain in nurses: a cross-sectional study. Pain Res Manag 2016;2016:9361016. [CrossRef]

3. Gaowgzeh RA. Low low back pain among nursing professionals in Jeddah, Saudi Arabia: prevalence and risk factors. J Back Musculoskelet Rehabil 2019;32(4):55-560. [CrossRef]

4. Li L, Deng X, Zhang H, Yang H, Chen J, Hou X, et al. A crosssectional survey of low low back pain in nurses working in orthopedic departments. Workplace Health Saf 2019;67(5):218-30. 
5. Guan J, Wu D, Xie X, Duan L, Yuan D, Lin H, et al. Occupational factors causing pain among nurses in Mainland China. Med Sci Monit 2019;25:1071-7. [CrossRef]

6. Yang S, Lu J, Zeng J, Wang L, Li Y. Prevalence and risk factors of work-related musculoskeletal disorders among intensive care unit nurses in China. Workplace Health Saf 2019;67(6):275-87. [CrossRef]

7. Tan BK, Smith AJ, O'Sullivan PB, Chen G, Burnett AF, Briggs AM. Low low back pain beliefs are associated to age, location of work, education and pain-related disability in Chinese healthcare professionals working in China: A cross sectional survey. BMC Musculoskelet Disord 2014;15:255.

8. Tsang VH, Lo PH, Lam FT, Chung LS, Tang TY, Lui HM, et al. Perception and use of complementary and alternative medicine for low back pain. J Orthop Surg (Hong Kong) 2017;25(3):2309499017739480. [CrossRef]

9. Silva OM, Proença MC, Vicari AR, Fengler KP, Karohl C, RabeIo-Silva ER. Occupational hazards for nursing professionals related to the reuse and single use of the dialyzer. Rev Esc Enferm USP 2018;13(52):e03389.

10. Mynarski W, Grabara M, Nawrocka A, Niestrój-Jaworska M, Wołkowycka B, Cholewa J. Physical recreational activity and musculoskeletal disorders in nurses. Med $\mathrm{Pr}$ 2014;65(2):181-8.
11. Patil NJ, Nagaratna R, Tekur P, Manohar PV, Bhargav H, Patil $D$. A randomized trial comparing effect of yoga and exercises on quality of life in among nursing population with chronic low back pain. Int J Yoga 2018;11(3):208-14. [CrossRef]

12. Sanjoy SS, Ahsan GU, Nabi H, Joy ZF, Hossain A. Occupational factors and low back pain: A cross-sectional study of Bangladeshi female nurses. BMC Res Notes 2017;10(1):173.

13. Van Hoof W, O'Sullivan K, O'Keeffe M, Verschueren $S$, O'Sullivan P, Dankaerts W. The efficacy of interventions for low low back pain in nurses: A systematic review. Int J Nurs Stud 2018;77:222-31. [CrossRef]

14. Şimşek Ş, Yağcı N, Şenol H. Prevalence of and risk facfors low low back pain among healthcare workers in Denizli. Agri 2017;29(2):71-8. [CrossRef]

15. Matsudaira K, Kawaguchi $M$, Isomura $T$, Inuzuka $K$, Koga T, Miyoshi K, et al. Assessment of psychosocial risk factors for the development of non-specific chronic disabling low low back pain in Japanese workersfindings from the Japan epidemiological research of occupation-related low back pain (JOB) study. Ind Health 2015;53(4):368-77. [CrossRef]

16. Barnish MS, Barnish J. High-heeled shoes and musculoskeletal injuries: a narrative systematic review. BMJ Open 2016;6(1):e010053. 